sciendo Порівняльна професійна педагогіка 8(2)/2018 Comparative Professional Pedagogy 8(2)/2018

DOI: $10.2478 /$ rpp-2018-0018

$\mathrm{PhD}$ in Economics, Full Professor, VADYM SIDOROV

V. N. Karazin Kharkiv National University, Ukraine

Address: 6 Maidan Sq, Kharkiv, 61022, Ukraine

E-mail: irtb@karazin.ua

\title{
INDIVIDUAL ASPECTS IN PROFESSIONAL TRAINING OF TOURISM SPECIALISTS IN THE UK
}

\begin{abstract}
The article deals with individual aspects in professional training of tourism specialists in the UK. It has been specified that alongside with the global development of tourism education, the UK revealed the potential of its tourism industry with the introduction of the Development of Tourism Act in 1969. Consequently, the tourism education in the UK has undergone three periods, namely, the establishment of the tourism industry and the comprehension of the need to prepare highly qualified tourism specialists, the development of tourism and hospitality courses, the large-scale foundation of higher education institutions offering tourism and hospitality courses. It has been clarified that the Quality Assurance Agency developed the Subject Benchmark Statement for Events, Hospitality, Leisure, Sport and Tourism, which is rather innovative and multidisciplinary, so that programme developers can take into consideration global challenges and needs of the modern labour market to prepare competitive specialists, who can become their own curriculum producers. It has been stated that future tourism specialists in the UK are fully supplied with innovative communication and information technologies and can pay much attention to developing practical skills while undergoing industrial placements, live casestudies, participating in volunteering activities, gain valuable professional experience due to advanced facilities. The following recommendations have been outlined to improve quality of future tourism specialists' professional training in Ukraine: 1) to develop relevant regulatory framework for professional tourism education; 2) to analyze the market of tourism supply and demand in order to define which tourism specialists are most required and, consequently, to expand a spectrum of specializations in professional training of tourism specialists; 3) to improve the state of facilities at higher education institutions offering tourism courses and provide students with the opportunity to gain valuable professional experience in modern technology-enhanced classrooms; 4) to increase the practical component of future tourism specialists' professional training through implementing industrial placements, work-based learning, direct collaborations with practitioners and employers, live case-studies, life performance and events, etc.; 5) to involve students into the design of their own curricula, so that they can feel themselves responsible for their learning outcomes.
\end{abstract}

Keywords: professional training, tourism specilaists, the UK, higher education, tourism education.

\section{INTRODUCTION}

The large-scale changes taking place in the 21 st century have urged modernization of education and, as a result, professional training of tourism specialists in Ukraine. The 
sciendo Порівняльна професійна педагогіка 8(2)/2018

Comparative Professional Pedagogy 8(2)/2018

fundamentally new socioeconomic situation has actualized the problem of providing the tourist industry in the country with highly qualified specialists, such as tour organizers and travel agents, managers and financiers, tour guides and guides-interpreter, hospitality specialists, specialists in information and advertising, management and marketing of tourism. At the core of the general programme for further development of tourism and the education system reforms in Ukraine, determination of sociopedagogical conditions for improving professional training of tourism specialists and development of their professional and entrepreneurial qualities are on the agenda.

However, theoretical analysis of theory and practice of professional tourism education in Ukraine has allowed distinguishing a range of contradictions between: 1) the growing demand for tourism services and the lack of modern specialists capable of meeting those needs; 2) the mass technologies of tourism services and the individual character of meeting tourism needs, which require to expand a spectrum of specializations in professional training of tourism specialists; 3 ) the changes in the structure of leisure activities and the underdeveloped system of tourism offers; 4) the striving of the tourism business subjects to introduce innovations into professional activity and the lack of the basic system of professional development and advanced training.

In addition, the rapid pace of the tourism industry development in Ukraine has caused the appearance of an abundance of higher education institutions engaged in professional training of tourism specialists. Still, the level of these specialists' professional training in many respects does not meet the requirements imposed both in the country and abroad.

Therefore, in order to solve the above-mentioned contradictions and increase the level of tourism specialists' professional training, it is imperative to thoroughly study innovative and relevant foreign experience. It must be noted that in the UK specificity in professional training of tourism specialists determines flexible adaptation to the changes in the structure of the education system and social life. Professional training of these specialists is conducted in close cooperation with all sectors of professional education such as universities, institutes and colleges. These trends eventually lead to a relative unification of curricula and programmes at the level of the training content.

\section{THE AIM OF THE STUDY}

Thus, the aim of the study is to analyze individual aspects in professional training of tourism specialists in the UK and attempt to provide relevant recommendations to improve quality of future tourism specialists' professional training in Ukraine.

\section{THEORETICAL FRAMEWORK AND RESEARCH METHODS}

Tourism education has undergone several periods of development, each facilitating the important principles and foundations of the industry. The development of the education system for professional training of tourism specialists is characterized by certain chronology. Thus, the main historical periods of formation and development of the system of tourism specialists' professional training are the following: the first period (the late $17^{\text {th }}$ century - the early $18^{\text {th }}$ century), the tourism industry emerged; the second period (the late $18^{\text {th }}$ century - the early $19^{\text {th }}$ century) - active learning in the context of tourism education was promoted due to dissemination and development of an excursion-based approach; the third period (the late $19^{\text {th }}$ century - the early $20^{\text {th }}$ century) - the events and personalities related to tourism and its educational effect were systemically comprehended; the fourth period - (the 40-50s of the $20^{\text {th }}$ century - the 70-80s of the $20^{\text {th }}$ century) - the development of the tourism infrastructure became top-priority; the strategy for professional training of tourism specialists was designed; the fifth period (the late $20^{\text {th }}$ century) - the modern period 
of tourism education development has started, which includes several systems of tourism specialists' professional training, the basic being European and American models (Klym, \& Zaiachuk, 2016, p. 101).

In the UK, until the 19th century, tourism started by being an activity undertaken only by the aristocrats. Despite the coming of age of the industry and despite the fact that the country believed in the potential of the tourism industry, it took time to take full responsibility of its tourism industry as it was mainly considered as the duty of the private sector (Thornberry, 2006). The first tourism administration in in the UK appeared in 1969 with the Development of Tourism Act. It is aimed at coordinating all the organisations that belong to the tourism sector and providing it with a single voice (Development of Tourism Act, 1969). It must be noted that there are currently no known outstanding changes to the document.

H. Séraphin \& Ch. Mansfield (2017) indicate that the development of tourism education in the UK consists of three periods, namely, the first period (1900-1959), the second period (1960-1989) and the third period (since 1990). Thus, the first period implies that the tourism industry in the UK is at its early stage: the first bodies in charge of tourism are established (British Tourist and Holidays (1947); British Travel Holidays Associations (1950)); motorways are being built (British Motorway Building Programme (1958)). So, in 1955 only 1 million tourists visited England (Middleton, 2005). During the second period one can observe a slight augmentation of the number of institutions offering tourism and hospitality courses (with slight decrease between 1970-1979); travelling becomes more popular; household income increases and the country is recovering from the damage caused by the World War II; the Development of Tourism Act (1969) contributes to the foundation of the English Tourist Board, so much so in the late 1960s tourism becomes one of the main source of income in the country (Middleton, 2005). However, V. Middleton (2005) specifies that the Robbins Report (1963) played the most important role in the development of courses in tourism and hospitality, since it provided more students with access to university education. In 1985, the UK reached the top 10 most visited destinations in the world (Middleton, 2005). Eventually, the third period is characterized by the decrease in the opening of higher education institutions offering courses in tourism and hospitality. This can be explained by a "saturation" of the market, but also the competition with private institutions offering similar courses for fewer prices (Chesworth, 2011).

D. Airey (2006b) suggests that tourism education in the UK began in 1972 with the introduction of two postgraduate programmes at the Universities of Strathclyde and Surrey. Tourism-related programmes existed before this date, notable for the hospitality sector where there were already bachelor degrees as well as diploma programmes (Airey, \& Tribe, 2000).

P. Petrova (2015) concludes that the development of tourism in higher education in the UK coincided with growth in higher education sector in general and the focus on higher education as an instrument of economic growth, the tourism higher education courses were largely established based on the research interests of tourism academics. Therefore, considerable importance is currently placed by universities and academics on research, as it is seen to secure the legitimacy of courses, universities and indeed individual academics.

It must be noted that the most prominent outcome of tourism education development, in our opinion, is marked with the introduction of the Subject Benchmark Statement for Events, Hospitality, Leisure, Sport and Tourism (EHLST) in 2000, with its further reconsideration in 2016. The document is multidisciplinary and encompasses a 
Sciendo Порівняльна професійна педагогіка 8(2)/2018

Comparative Professional Pedagogy 8(2)/2018

range of theory and practice from social to physical sciences, and in particular from business and management, which are efficiently intervened into tourism and hospitality programmes.

So, based on generalization and systematization of the above-mentioned data on the history of tourism education in general and in the UK in particular, we have shown the paradigm of tourism education development, specified relevant factors affecting its development and outlined the current state of tourism education in the country. Due to theoretical framework of the research, we will be able to analyze and synthesize individual aspects in professional training of tourism specialists in the UK and consequently generate reasonable recommendations to enhance quality of professional training of these specialists in Ukraine and solve the outlined contradictions in the introduction section.

\section{RESULTS}

The United Nations World Tourism Organization (UNWTO) has developed the frameworks of general characteristics and accreditation standards for tourism. Modern studies analyze the possibility of implementing the international tourism workforce qualification test, which should assess future tourism specialists' abilities to conduct professional activity efficiently. This will encourage them to participate in lifelong learning, create the relevant necessary conditions for career growth and provide them with an opportunity to improve professional knowledge and skills. Consequently, international organizations involved in the development of the tourism industry and the enhancement of quality of tourism specialists' professional training have put forward requirements for the tourism industry and tourism education and identified the following specific objectives in professional tourism education: a) creating favorable opportunities for developing and improving the education process and professional training of tourism specialists; b) providing leadership and initiative in tourism education; c) developing the necessary educational strategies in higher education institutions, which offer tourism and hospitality courses in order to achieve quality and efficiency of education; d) creating the tourism product of high quality with modern properties due to using highly competitive strategies; e) developing strategic guidelines for higher education modernization; f) the striving to take professional tourism education to the level of the most prominent achievements in science and technology; g) developing professional tourism and hospitality courses in accordance with the modern needs of the labour market; providing the teaching-based component of tourism and hospitality courses in common languages; h) improving the structure of the multi-level system of professional tourism education; i) designing international standards of tourism education, as well as incorporating new tourism professions, developing efficient textbooks, manuals, recommendations; j) elaborating the regulatory framework for new types of professional institutions of tourism education (Tkach, 2016).

As evidenced by Kings Education (2018), a high quality international education group across the UK, hospitality and tourism courses in higher education institutions in the UK are characterized by many advantages, namely, the language component, the location, top rankings of the universities, a direct link with practice and experience, an extended period of work placement in the industry. Indeed, the UK is rather famous for the top universities in the world. Due to the mixture of skills it requires, hospitality management incorporates the aspects of business management, media and communications, and modern languages and universities in the UK all excel in the study of these subjects. Teaching and learning in the UK are firmly based on case studies and practical knowledge. The sector requires graduates who have solid knowledge of the industry and who can take the right decisions and this is only possible due to direct practical experience. Most importantly, 
tourism and hospitality specialists are provided with excellent career opportunities in such areas as tour operation, travel agency management, tourism transportation services, hotel and resort management, restaurant management, contract and event management and catering, cruise ship operations, golf club management, leisure centre management (Kings Education, 2018).

Tourism is typically offered as a discrete subject or linked with leisure studies for the general and vocational qualifications. For the occupational awards, which are primarily competency-based, the awards are linked to a range of specific tourism jobs such as a tour guides, museum officers, publicity assistants, tourist information officers, travel consultants and travel services (Airey, 2006b). However, D. Airey (2006b) indicates "the most important point to emphasize is that the provision is widespread at all levels" (p. 273). M. Stuart (2002) specifies that the role of the individual lecturer and concerns about academic respectability (seen in the continuing tension between an academic and a vocational focus for the subject) are the two influences, which have had the greatest impact on the subject's development (p. 14).

In the UK, professional courses on tourism and hospitality are mainly offered by business schools or schools of management (University of Birmingham, University of Brighton, University of Buckingham, University of Edinburgh, University of Kent, University of Newcastle, University of Reading, University of Surrey, etc.). Some universities have their own tourism and hospitality departments (Oxford Brooke University, Thames Valley University, Manchester Metropolitan University). It must be noted that there is no consistency in the names of the programmes at the level of higher education. The most popular title (approximately $20 \%$ ) is "Tourism Management" followed by "Tourism", "Leisure and Tourism Management", "Tourism Studies", "Tourism and Hospitality Management" etc.

M. Stuart-Hoyle (2003) notes that there is a trend for institutions seeking to differentiate themselves from one another by drawing on lecturer's distinct research and other interests and experience. She points to these being translated into new special interest optional courses offered as a part of the programme hence allowing the institution to form a distinct identity.

As evidenced by the Subject Benchmark Statement for Events, Hospitality, Leisure, Sport and Tourism (2016), EHLST subjects are particularly sensitive and responsive to changes in the world environment. This is reflected in the increasing inclusion in degree programmes of opportunities for students to consider the issues of internationalization, environmental sustainability, ethical positioning, social responsibility and social justice, global security and risk, crisis management and other contemporary issues (p. 7).

Since this Subject Benchmark Statement consists of five interrelated areas, each area still encompasses its specific sub-areas. For instance, the curriculum content for the events area may include the events industry, public relations, event policy, event law and licensing, event production, event environment, organisational behaviour, event operations, event design, theming, event marketing, event risk management, venue and facilities management, live events management, mega-events and spectacle, etc. The hospitality area may incorporate such sub-areas as food science and microbiology, food safety, food and beverage production and service, culinary arts, quality assurance, organizational behaviour, consumer behaviour, entrepreneurship, financial management, small business management, leisure management, tourism etc. As for the leisure area, it consists of such sub-areas as leisure philosophy, leisure conceptions, leisure policies, leisure history, leisure sociology, leisure environment, leisure and planning, strategies for leisure, leisure operations, leisure events, leisure resources management, digital leisure, arts and entertainment, rural leisure, 
exercise and fitness, health and well-being, recreation etc. The curriculum for tourism involves tourism and globalisation, tourism geography, sustainable tourism, tourism policy, strategic planning in tourism, operation of the tourism industry, tourism economics, entrepreneurship in tourism, tourism marketing, technology in travel and tourism, visitor management, etc.

D. Airey (2006b) states that notwithstanding the attempts of differentiation, in reality the curricula of tourism and hospitality programmes remain remarkably similar across institutions. At the university level the curriculum has tended to broaden outwards for its essentially business-oriented vocational origins (Airey, 2006a). He analyzed those tourism programmes, which are mostly focused on business, management and links with industry. The findings are presented in Table 1.

Tourism course - BA (Hons) Tourism

Table 1

\begin{tabular}{|l|l|}
\hline Year 1 & $\begin{array}{l}\text { Introduction to Tourism; Information; People, World and Tourism; Tourism Economics; Tourism } \\
\text { Environments; Law, Accounting and Finance; Residential Field Trip }\end{array}$ \\
\hline Year 2 & $\begin{array}{l}\text { Assessment of Tourism Resources; Administration of Tourism; Law Related to Tourism; Tourism } \\
\text { Marketing; Human Resource Management; Economics and Finance of Tourism Operations; } \\
\text { Research Methods; Residential Field Trip }\end{array}$ \\
\hline Year 3 & Industry-based Placements \\
\hline Year 4 & Business and Tourism; Tourists and Destinations; Optional Courses; Dissertation \\
\hline
\end{tabular}

Source: Airey, D. (2006a)

Thus, one can see the overwhelming importance of training for a career in tourism as well as the significance of business and management skills as a part of programmes. It must be noted that the study modes for EHLST subjects vary: from full-time and part-time, sandwich and distance learning, as well as individual components of technology-based learning. Industrial placements, work-based learning involving a direct collaboration between higher education institutions, practitioners and employers play an important role in professional training of these specialists. In such a way, specialists gain valuable practical experience, develop the knowledge and skills which they will definitely need in professional activity.

The Subject Benchmark Statement for Events, Hospitality, Leisure, Sport and Tourism (2016) provides for teaching, learning and assessment to incorporate different theoretical and applied approaches, whereas choosing an approach depends on the learning outcomes expected of students. Most importantly, higher education providers assist their students in designing their own curricula, so that they may be co-producers.

As evidenced by the document, lectures, seminars, workshops, laboratory work, practical classes, individual and group tutorials, real-time practice, case studies, industrial placements, blended learning, technology-based learning, live performance and events, independent work are the most common learning and teaching methods with EHLST curricula.

The learning opportunities for British students who pursue career in EHLST are of great importance. Thus, they include periods of volunteering activities, using specialized items of equipment (training kitchens and restaurants, sports science laboratories, venues and event specific facilities, leisure facilities etc.), engaging in field work in the internal/ external environment, live case-studies etc.

Higher education institutions in the UK apply different assessment methodologies to effectively assess future specialists' knowledge and skills acquired through mastering the 
programmes. They provide for assessing the results of live practice, the students' ability to combine theoretical and practical experience with the help of problem-based approaches to reveal their understanding of the programme's core.

\section{CONCLUSIONS}

So, based on the study conducted, we can conclude that the development of tourism education has started quite recently and have consisted of five periods so far. They have covered the emergence of the tourism industry, the promotion of active learning in the context of tourism education, the comprehension of tourism and its educational effect, the development of the tourism infrastructure, as well as strategies for tourism specialists' professional training, the origination of different models in tourism education (in particular, European and American models). Alongside with the global development of tourism education, the UK revealed the potential of its tourism industry with the introduction of the Development of Tourism Act in 1969. Consequently, the tourism education in the UK has undergone three periods, namely, the establishment of the tourism industry and the comprehension of the need to prepare highly qualified tourism specialists, the development of tourism and hospitality courses, the large-scale foundation of higher education institutions offering tourism and hospitality courses.

Most importantly, the Quality Assurance Agency developed the Subject Benchmark Statement for Events, Hospitality, Leisure, Sport and Tourism in 2000, with its further reconsideration in 2016. The document is rather innovative and multidisciplinary, since it encompasses these core subjects such as events, hospitality, leisure, sport and tourism, so that programme developers can take into consideration global challenges and needs of the modern labour market to prepare competitive specialists, who can become their own curriculum producers. Considering the scope of learning, teaching and assessment provided for the Subject Benchmark Statement, we can conclude that future tourism specialists in the UK are fully supplied with innovative communication and information technologies and can pay much attention to developing practical skills while undergoing industrial placements, live case-studies, participating in volunteering activities, gain valuable professional experience due to advanced facilities (training kitchens and restaurants, sports science laboratories, venues and event specific facilities, etc.).

We believe it necessary to outline the following recommendations to improve quality of future tourism specialists' professional training in Ukraine: 1) to develop relevant regulatory framework for professional tourism education; 2) to analyze the market of tourism supply and demand in order to define which tourism specialists are most required and, consequently, to expand a spectrum of specializations in professional training of tourism specialists; 3) to improve the state of facilities at higher education institutions offering tourism courses and provide students with the opportunity to gain valuable professional experience in modern technology-enhanced classrooms; 4) to increase the practical component of future tourism specialists' professional training through implementing industrial placements, work-based learning, direct collaborations with practitioners and employers, live casestudies, life performance and events, etc.; 5) to involve students into the design of their own curricula, so that they can feel themselves responsible for their learning outcomes.

As evidenced by the research, it is still necessary to further study practical experience of British higher education institutions in organizing professional training of future tourism specialists. 
S sciendo Порівняльна професійна педагогіка 8(2)/2018

Comparative Professional Pedagogy 8(2)/2018

\section{REFERENCES}

1. Airey, D. (2006a). Chapter 2. Growth and development. D. Airey \& J. Tribe (Eds.), An International Handbook of Tourism Education (pp. 13-24). Amsterdam: Elsevier.

2. Airey, D. (2006b). Chapter 19. United Kingdom. D. Airey \& J. Tribe (Eds.), An International Handbook of Tourism Education (pp. 271-282). Amsterdam: Elsevier.

3. Airey, D., \& Tribe, J. (2000). Education for hospitality. In C. Lashley \& A. Morrison (Eds.), In Search for Hospitality: Theoretical Perspectives and Debates (pp. 192-276). Oxford: Butterworth Heinemann.

4. Chesworth, N. (2011). A degree with distinction. Metro, 7, p. 54

5. Development of Tourism Act 1969. (1969).

6. Kings Education. (2018). Tourism and hospitality in the UK. Retrieved from https://www.kingseducation.com/landing-pages/pathways-in-tourism-and-hospitality-inthe-uk/tourism-and-hospitality-in-the-uk.html.

7. Klym, A., \& Zaiachuk, O. (2014). Rozvytok systemy osvity v turyzmi (vitchyznianyi ta zarubizhnyi dosvid). Naukovyi visnyk Chernivetskoho universytetu. Heohraphiia, 696, 101-104.

8. Middleton, V. T. C. (2005). British tourism, the remarkable story of growth. London: Butterworth Heinemann.

9. Petrova, P. (2015). The evolution of the employability skills agenda in tourism education. In D. Dredge, D. Airey \& M. J. Gross (Eds.), The Routledge Handbook of Tourism and Hospitality Education (pp. 383-394). London; New York: Routledge.

10. Quality Assurance Agency. (2016). Subject benchmark statement for events, hospitality, leisure, sport and tourism. Retrieved from http:/www.qaa.ac.uk/en/Publications/ Documents/SBS-Events-Hospitality-Leisure-Sport-Tourism-16.pdf.

11. Séraphin, H., \& Mansfield, Ch. (2017). A comparative study of tourism and hospitality education in the United Kingdom and France. The Journal of Applied Ceremonial and Communication in Management, 2, 55-95.

12. Stuart, M. (2002). Critical influences on tourism as a subject in UK higher education: lecturer perspectives. Journal of Hospitality, Leisure, Sport \& Tourism Education, $1(1), 5-18$.

13. Stuart-Hoyle, M. (2003). The purpose of undergraduate tourism programmes in the United Kingdom. Journal of Hospitality, Leisure, Sport \& Tourism Education, 2 (1), 49-74.

14. Thornberry, A. (2006). The skills shortage in tourism: solving the problem. The Tourism Society Journal, 127, 28.

15. Tkach, V. O. (2016). Suchasna systema osvity v turystychnii industrii. Ukrainskyi zhurnal prykladnoi ekonomiky, 1 (3), 102-108. 